Article

\title{
Dehydration of bio-ethanol to ethylene over iron exchanged HZSM-5
}

\author{
Baohui Chen ${ }^{\mathrm{a}, \mathrm{b}, *}$, Jiazheng $\mathrm{Lu}^{\mathrm{a}}$, Lianping $\mathrm{Wu}^{\mathrm{b}}$, Zisheng Chao ${ }^{\mathrm{b}}$ \\ a State Key Laboratory of Disaster Prevention \& Reduction for Power Grid Transmission and Distribution Equipment, Hunan Electric Power Corporation \\ Disaster Prevention and Reduction Center, State Grid Key Laboratory of Power Transmission and Distribution Equipment Anti-Icing \& Reducing-Disaster \\ Technology, Changsha 410007, Hunan, China \\ b State Key Laboratory of Chemo/ Biosensing and Chemometrics, College of Chemistry and Chemical Engineering, Hunan University, Changsha 410082, \\ Hunan, China
}

\section{A R T I C L E I N F O}

\section{Article history:}

Received 27 May 2016

Accepted 3 August 2016

Published 5 November 2016

\section{Keywords:}

Iron

ZSM-5

Dehydration

Ethanol

Ethylene

\begin{abstract}
A B S T R A C T
Iron exchanged ZSM-5 with Si/Al ratio from 25 to 300 prepared by three consecutive ion exchanges was used for the dehydration of ethanol to ethylene. The iron exchanged ZSM-5 $(\mathrm{Si} / \mathrm{Al}=25)$ catalyst with an iron content of 0.46 wt $\%$ gave $97 \%-99 \%$ yield of ethylene at $98 \%-99 \%$ conversion of ethanol at $260{ }^{\circ} \mathrm{C}$ and $0.81 \mathrm{~h}^{-1}$ liquid hourly space velocity. The high performance was maintained for $60 \mathrm{~d}$ on-stream. X-ray diffraction, Fourier transform infrared spectroscopy of pyridine adsorption, $\mathrm{NH}_{3}$ temperature-programmed desorption and diffuse reflectance UV-vis spectroscopy were used for catalyst characterization. Ion exchange with iron decreased the total acidity of the zeolite, especially the strong acid sites and Brönsted acid sites. The doped iron species were distributed over Fe-ZSM-5 as predominantly isolated $\mathrm{Fe}^{3+}$. Therefore, the catalytic performance for ethanol dehydration to ethylene was improved.
\end{abstract}

(C) 2016, Dalian Institute of Chemical Physics, Chinese Academy of Sciences. Published by Elsevier B.V. All rights reserved.

\section{Introduction}

Ethylene is one of the most important chemicals with a large demand and production. The manufacture of ethylene in industry currently is by the thermal cracking of liquefied petroleum gas or naphtha [1]. This is, however, confronted with the challenges of decreasing petroleum resources and severe environmental problems. As is known, bio-ethanol is a renewable material and it is now produced on a large scale through fermentation processes [1-4]. Therefore, the catalytic conversion of ethanol offers a green route to the production of ethylene and has been paid more attention [1-14].

Currently, many catalysts have been developed for ethanol dehydration to ethylene, including oxides $[11,12,15]$, hetero- polyacids [8,16] and zeolites [5,17-21]. A 98.7\% ethylene yield was obtained at $460{ }^{\circ} \mathrm{C}$ by a $\mathrm{TiO}_{2} / \gamma-\mathrm{Al}_{2} \mathrm{O}_{3}$ catalyst [12]. Dogu's group [16] developed heteropolyacid catalysts for use at low reaction temperature; however, the ethylene selectivity was only $77.0 \%$ at $250{ }^{\circ} \mathrm{C}$. Zeolites have been widely used in many fields, such as environmental decontamination, the detergent industry, and catalysis. Since the 1980s, researchers have used zeolites for the dehydration of ethanol to ethylene [1]. The zeolites used were ZSM-5, $\beta$ zeolite, Si-Al-phosphate (SAPO) zeolite, A type zeolite, and AM-11 type zeolite [1]. Among these zeolite catalysts, the most promising is ZSM-5 zeolite $[1,2,4,18,22-24]$, which has many obvious merits, such as a regular pore structure, outstanding thermal and hydrothermal stability, low formation of coke, high surface area, and adjusta-

\footnotetext{
* Corresponding author. Tel/Fax: +86-731-86332074; E-mail: bymountains@gmail.com

This work was supported by the National Natural Science Foundation of China (21376068) and the China Postdoctoral Science Foundation (2016M592424).
}

DOI: 10.1016/S1872-2067(16)62524-X | http://www.sciencedirect.com/science/journal/18722067 | Chin. J. Catal., Vol. 37 , No. 11, November 2016 
ble acidity [25]. Guo's group [4] studied a nano-scale HZSM-5 zeolite that gave $>98.43 \%$ ethylene selectivity at $>98.40 \%$ conversion at $240{ }^{\circ} \mathrm{C}$ for $630 \mathrm{~h}$. Zhao's group [2] used a steam treated HZSM-5 zeolite as the catalyst for the ethanol hydration to ethylene and obtained $>90 \%$ ethylene yield at $275{ }^{\circ} \mathrm{C}$; this excellent performance could be maintained for $350 \mathrm{~h}$. Besides these, metal-modified HZSM- 5 zeolite catalysts were also studied [18,24]. Le Van Mao et al. [24] investigated bioethanol dehydration to ethylene using a ZSM-5/Zn-Mn catalyst. The result showed that when the reaction temperature reached $400{ }^{\circ} \mathrm{C}$, the conversion of ethanol was $96 \%$ and the selectivity to ethylene was $49 \%$. Ouyang et al. [18] performed ethanol dehydration to ethylene over La-doped ZSM-5 zeolite. The stability measurement in the laboratorial bioreactor displayed that both the conversion of ethanol and selectivity to ethylene over this catalyst was maintained at $>98 \%$ for $>950 \mathrm{~h}$ at $260^{\circ} \mathrm{C}$.

Iron doped ZSM-5 was verified to be active for the transformation of ethanol into hydrocarbons [14,26-30]. The hydrocarbon product consisted of predominantly $\mathrm{C}_{1}-\mathrm{C}_{9}$ hydrocarbons, i.e., alkanes, olefins and aromatics. However, in the literature, a high iron loading (up to $10 \mathrm{wt} \%$ [30]), ZSM-5 with a relatively high $\mathrm{Si} / \mathrm{Al}$ ratio ( $>40[26,31])$, and high reaction temperature (up to $400{ }^{\circ} \mathrm{C}[27,30]$ ) were used. As a result, in the conversion of ethanol, $\mathrm{C}^{3+}$ olefins and aromatic compounds were the main products [30,31].

In this paper, the dehydration of ethanol to ethylene was carried out over an iron exchanged ZSM- 5 with the Si/Al ratio ranging from 25 to 300 . The iron exchanged ZSM-5 catalyst with a low $\mathrm{Si} / \mathrm{Al}$ ratio exhibited a high catalytic performance for ethanol dehydration to ethylene at a low reaction temperature. The structure and properties of H-ZSM-5(25) and Fe-ZSM-5(25) catalysts were also studied.

\section{Experimental}

\subsection{Preparation of catalysts}

HZSM-5 powder (purchased from Fuxu Zeolite Corporation, China) with different molar ratios of $\mathrm{Si} / \mathrm{Al}=25-300$ was first calcined in air at $550{ }^{\circ} \mathrm{C}$ for $4 \mathrm{~h}$. Iron (Fe) exchanged ZSM-5 catalyst was obtained by three consecutive ion exchanges of HZSM-5 with aqueous solutions of iron nitrate $\left(\mathrm{Fe}\left(\mathrm{NO}_{3}\right)_{2} \cdot 9 \mathrm{H}_{2} \mathrm{O}\right)$. First, the calcined powder of HZSM-5 was dispersed into a $0.3 \mathrm{~mol} / \mathrm{L}$ aqueous solution of metal nitrate salt using $10 \mathrm{~mL}$ solution per gram of zeolite. The $\mathrm{pH}$ of the solution was controlled at 1.5 in accordance with previous papers [26,31]. After that, the resulting mixture was magnetically stirred at $25{ }^{\circ} \mathrm{C}$ for $12 \mathrm{~h}$. After filtration, rinsing and drying at $120{ }^{\circ} \mathrm{C}$, the catalyst was calcined at $550{ }^{\circ} \mathrm{C}$ for $4 \mathrm{~h}$. The as-prepared catalyst was named as Fe-ZSM- $5(X)$, where $X$ refers to the $\mathrm{Si} / \mathrm{Al}$ molar ratio of the ZSM- 5 zeolite. Before it was used in the reaction, the catalyst was pressed, crushed and sieved into the 20-30 mesh fraction. The iron content of Fe-ZSM-5(25) was determined by flame atomic absorption spectrometry (performed by a Varian AA240 apparatus). The result showed that the Fe-ZSM-5(25) catalyst possessed an iron content of 0.46 wt $\%$.

\subsection{Catalyst characterization}

X-ray diffraction (XRD) was carried out with a Bruker D8-Advance X-ray diffraction equipment with $\mathrm{Cu} K_{\alpha}$ radiation operated on $40 \mathrm{kV}$ and $40 \mathrm{~mA}$. The pattern was recorded over the $2 \theta$ angle ranging from $5^{\circ}$ to $80^{\circ}$ at a scan rate of $5^{\circ} / \mathrm{min}$. $\mathrm{NH}_{3}$ temperature-programmed desorption ( $\mathrm{NH}_{3}-\mathrm{TPD}$ ) was conducted by employing a Quantachrome Autosorb-1 analyzer with a TCD. The catalyst was first heated at a rate of $10^{\circ} \mathrm{C} / \mathrm{min}$ from room temperature to $450{ }^{\circ} \mathrm{C}$ and pretreated at that temperature for $0.5 \mathrm{~h}$ under argon. After it was cooled to $100{ }^{\circ} \mathrm{C}$, the catalyst was subjected to $\mathrm{NH}_{3}$-saturation in a stream of $5 \%$ $\mathrm{NH}_{3} / \mathrm{He}$ with a flow rate of $40 \mathrm{~mL} / \mathrm{min}$. After purging with helium at $100{ }^{\circ} \mathrm{C}$ for $0.5 \mathrm{~h}, \mathrm{NH}_{3}$ was desorbed by heating the catalyst to $650^{\circ} \mathrm{C}$ at a rate of $15^{\circ} \mathrm{C} / \mathrm{min}$.

Fourier transform infrared (FT-IR) spectroscopy of pyridine adsorption was recorded using a Varian 3100 spectrometer equipped with a liquid nitrogen cooled MCT detector. The resolution and scan number were $4 \mathrm{~cm}^{-1}$ and 32, respectively. First, the catalyst was ground and dispersed in $\mathrm{KBr}$ powders (mass ratio $=33 / 100$ ). Then, it was pressed into a disc and pre-heated at $400{ }^{\circ} \mathrm{C}$ for $4 \mathrm{~h}$ under $\mathrm{N}_{2}$ in a Harrick in situ IR cell. After it was cooled to room temperature, the catalyst was exposed to pyridine vapor for $1.5 \mathrm{~h}$. The catalyst was heated at $250{ }^{\circ} \mathrm{C}$ for $1.5 \mathrm{~h}$ in a $\mathrm{N}_{2}$ atmosphere, followed by exposure to 0.1 $\mathrm{MPa}$ vacuum at room temperature for $3 \mathrm{~h}$ for removing gaseous and physisorbed pyridine molecules. Then the catalyst was used for the FT-IR measurement. Diffuse reflectance spectroscopy (DRS UV-VIS) was conducted by using a Perkin Elmer Lambda 35 spectrometer equipped with a $60 \mathrm{~mm}$ integrating sphere using $\mathrm{BaSO}_{4}$ as standard.

\subsection{Catalytic reaction}

The catalytic reaction was performed in an electrically heated fixed bed reactor (i.d. $=10 \mathrm{~mm}$, length $=400 \mathrm{~mm}$ ). Catalyst granules $(3 \mathrm{~g})$ were charged into the middle of reactor. Before reaction, the temperature was raised to a preset one in the range of $200-320^{\circ} \mathrm{C}$. Bio-ethanol (60 wt\% aqueous solution) was directly pumped into the reactor by a micro-pump without prior gasification or any diluent gas. The liquid hourly space velocity (LHSV) was controlled at $0.84 \mathrm{~h}^{-1}$. Gaseous and liquid products from the bottom of the reactor were passed through a gas-liquid separator. The gaseous products were analyzed by a TCD gas chromatograph (PE Clarus 500) with a Porapak Q column. The liquid products were analyzed by an FID gas chromatograph (Shandong Lunan SP-2000B GC) with a SE-54 column. The conversion (denoted as $\chi$ ) and product selectivities (denoted as $S_{i}$ ) were calculated in accordance with a previous paper [20].

\section{Results and discussion}

\subsection{Characterization of the catalysts}

Fig. 1 shows the XRD patterns of HZSM-5(25) and Fe-ZSM-5(25). Both patterns present a set of diffraction peaks 


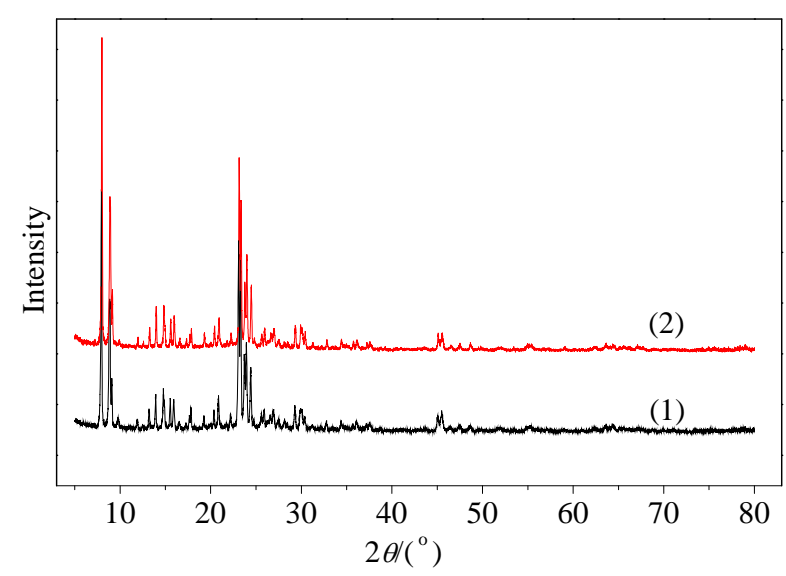

Fig. 1. XRD patterns of (1) HZSM-5(25) and (2) Fe-ZSM-5(25).

at $2 \theta=7.9^{\circ}, 8.8^{\circ}, 23.0^{\circ}, 23.2^{\circ}, 23.6^{\circ}, 23.9^{\circ}$ and $24.4^{\circ}$, indicating that these two catalysts possess the same ZSM- 5 zeolite structure. For the Fe-ZSM-5 catalyst, besides the peaks assigned to ZSM-5, no other peak was observed. These observations showed that the ion exchange process neither deteriorated the crystal structure of ZSM-5 zeolite nor generated a new phase detectable by XRD.

Fig. 2 shows the FT-IR spectra of pyridine adsorption on HZSM-5(25) and Fe-ZSM-5(25). Bands at 1540 and $1450 \mathrm{~cm}^{-1}$ were present. These can be assigned to Brönsted and Lewis acid sites, respectively [32]. One can see that both the bands for the Brönsted and Lewis acid sites showed changes in their integrated areas with the catalyst, indicating variations in the concentrations of the Brönsted and Lewis acid sites. The ratio of the integrated areas of the bands at 1540 and $1445 \mathrm{~cm}^{-1}$ can be employed to evaluate the relative concentration of Brönsted and Lewis acid sites [33]. These ratios, denoted as $\mathrm{B} / \mathrm{L}$, for the different catalysts are summarized in Table 1 . One can see that the Fe-ZSM-5(25) catalyst has an obviously lower B/L value than the HZSM-5(25) zeolite.

Fig. 3 shows the $\mathrm{NH}_{3}$-TPD profiles of HZSM-5(25) and Fe-ZSM-5(25). The peaks in these desorption profiles can be classified into two groups, low-temperature peaks (LT; $<300$

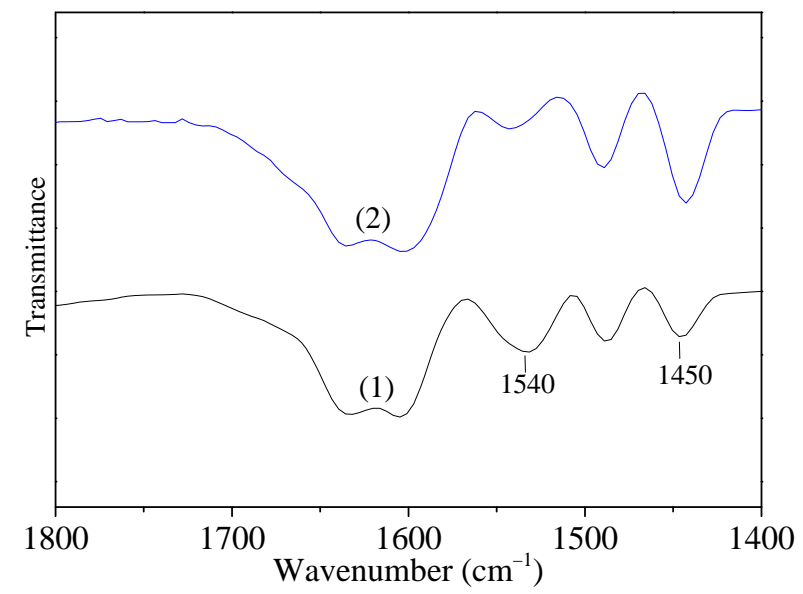

Fig. 2. FT-IR of pyridine adsorption of (1) HZSM-5(25) and (2) Fe-ZSM-5(25).
Table 1

Acidity and acid site amounts of the catalysts determined by $\mathrm{NH}_{3}$-TPD.

\begin{tabular}{|c|c|c|c|c|c|c|c|}
\hline \multirow[b]{2}{*}{ Catalyst } & \multicolumn{2}{|l|}{ LT } & \multicolumn{2}{|l|}{ HT } & \multirow[b]{2}{*}{$\Sigma C$} & \multirow[b]{2}{*}{$C_{\mathrm{H}} / C_{\mathrm{L}}$} & \multirow[b]{2}{*}{$B / L$} \\
\hline & $\begin{array}{c}\begin{array}{c}C_{\mathrm{L}} \\
(\mathrm{mmol} / \mathrm{g})\end{array} \\
\end{array}$ & $\begin{array}{l}T_{\mathrm{m}, \mathrm{L}} \\
\left({ }^{\circ} \mathrm{C}\right)\end{array}$ & $\begin{array}{c}C_{\mathrm{H}} \\
(\mathrm{mmol} / \mathrm{g})\end{array}$ & $\begin{array}{l}T_{\mathrm{m}, \mathrm{H}} \\
\left({ }^{\circ} \mathrm{C}\right) \\
\end{array}$ & & & \\
\hline HZSM-5(25) & 0.147 & 202 & 0.102 & 469 & 0.249 & 0.70 & 1.42 \\
\hline Fe-ZSM-5(25) & 0.121 & 215 & 0.038 & 438 & 0.159 & 0.29 & 0.25 \\
\hline
\end{tabular}

Notes: $C$ and $T_{\mathrm{m}}$ refer to the concentration of acid sites and temperature of the desorption peak at its maximum; $\Sigma C$ refers to the total acidity; $C_{\mathrm{H}} / C_{\mathrm{L}}$ is the area ratio of HT acid sites to LT acid sites; $\mathrm{B} / \mathrm{L}$ is the concentration rate of Brönsted to Lewis acid sites determined by FT-IR of pyridine adsorption.

${ }^{\circ} \mathrm{C}$ ) and high-temperature ones (HT; $\left.>300{ }^{\circ} \mathrm{C}\right)$. The concentration of acid sites $(C)$ and temperature for the maximum of the peaks $\left(T_{\mathrm{m}}\right)$ are listed in Table 1 . The distribution of acid sites was also calculated from the TPD profiles by the deconvolution method. The ratios of the concentration of HT acid sites to LT acid sites, denoted as $C_{\mathrm{H}} / C_{\mathrm{L}}$, were also calculated. HZSM-5(25) exhibited a LT peak at $202^{\circ} \mathrm{C}$ and a HT peak at $469^{\circ} \mathrm{C}$, suggesting that two types of acid sites were present. Fe-ZSM- 5 showed a clear decrease in the total acidity relative to the pristine HZSM-5 zeolite. Compared to HZSM-5(25), for Fe-ZSM-5(25), the LT peak increased to the higher temperature at $215^{\circ} \mathrm{C}$. However, the HT peak decreased to a lower temperature (438 ${ }^{\circ} \mathrm{C}$ ).

Fig. 4 shows the UV-VIS spectra of HZSM-5(25) and Fe-ZSM-5(25). The electronic spectrum in the UV-visible region is a useful technique for studying the electronic state of isolated transition metal ions. According to the literature [34,35], the UV/VIS spectrum is especially sensitive to the charge transfer bands of the iron ion. The wavelength of the bands reflects the coordination number and the degree of aggregation. One can see that HZSM-5(25) showed a strong band at $240 \mathrm{~nm}$, which is related to the Al units of the $T_{1}$ transition charge transfer processes [36]. In comparison, Fe-ZSM-5(25) exhibited three characteristic absorptions at 232, 277, and $357 \mathrm{~nm}$. In Brückner's work [34], the bands below $300 \mathrm{~nm}$ were ascribed to isolated $\mathrm{Fe}^{3+}$ sites. Their position depends on the number of ligands. In the present work, the band at $232 \mathrm{~nm}$ was attributed to isomorphously incorporated $\mathrm{Fe}^{3+}$ ions in the zeolite framework

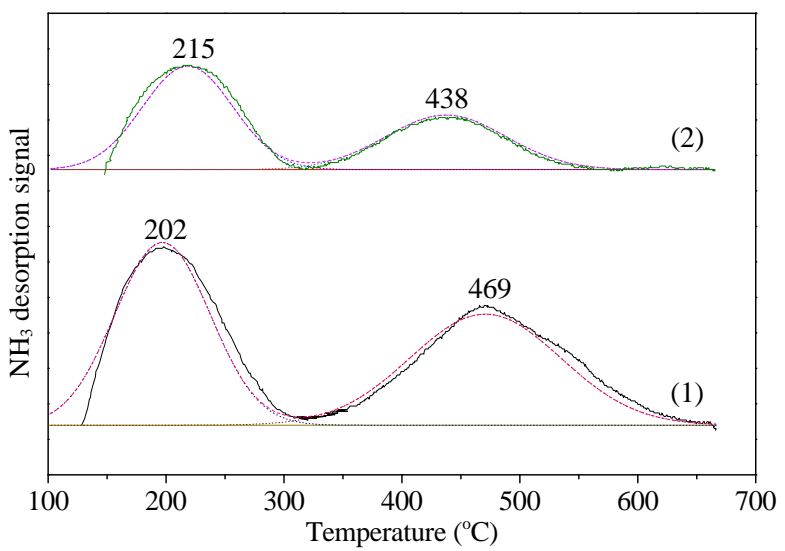

Fig. 3. $\mathrm{NH}_{3}-\mathrm{TPD}$ profiles of (1) HZSM-5(25) and (2) Fe-ZSM-5(25). 


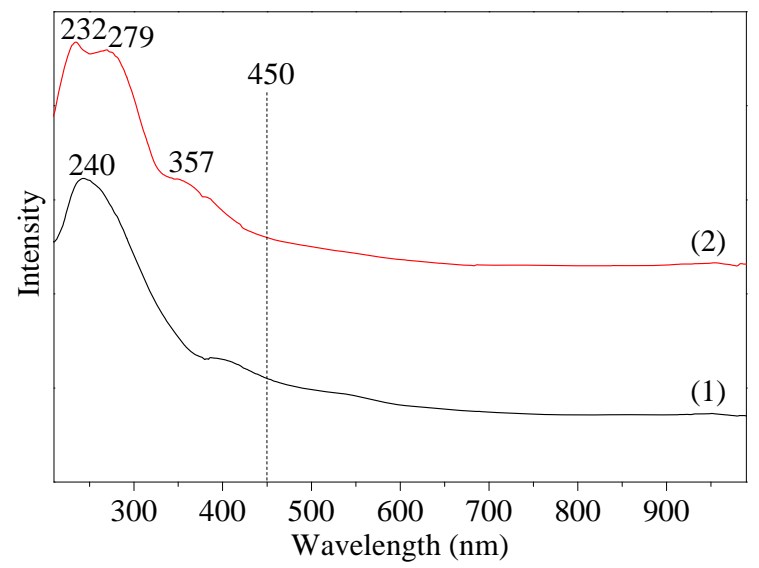

Fig. 4. DRS UV-VIS spectra of (1) HZSM-5(25) and (2) Fe-ZSM-5(25).

with tetrahedral or higher coordination $[34,36]$, and the band at $277 \mathrm{~nm}$ to isolated extraframework $\mathrm{Fe}^{3+}$ sites in octahedral coordination [37]. Thus, we concluded that framework and extraframework $\mathrm{Fe}^{3+}$ were present simultaneously in Fe-ZSM-5(25). The small band at $357 \mathrm{~nm}$ was associated with the iron ions of small oligomeric $\mathrm{Fe}_{x} \mathrm{O}_{y}$ clusters $[34,38]$. There was hardly any band that can be attributed to large $\mathrm{Fe}_{2} \mathrm{O}_{3}$ particles, which would show bands above $450 \mathrm{~nm}$ [34,35], observed. These results suggested that the Fe species was distributed over the Fe-ZSM-5 catalyst predominantly as isolated framework and extraframework $\mathrm{Fe}^{3+}$, and a small amount of oligomeric $\mathrm{Fe}_{x} \mathrm{O}_{y}$ clusters. However, hardly any large $\mathrm{Fe}_{2} \mathrm{O}_{3}$ particles existed.

\subsection{Dehydration of ethanol to ethylene over the catalysts}

The Si/Al ratio of the zeolites remarkably affected the distribution and strength of the surface acid sites which played a vital role in the dehydration of ethanol to ethylene [10]. Fig. 5(a) shows the dehydration of ethanol to ethylene over $\mathrm{HZSM}-5(X)$ as a function of the $X$ (Si/Al ratio) value. The reaction temperature was $230^{\circ} \mathrm{C}$. One can see that the conversion of ethanol increased first, and reached a maximum (79.2\%) at the $\mathrm{Si} / \mathrm{Al}$ ratio of 100 , and then it decreased with the further increase of the $\mathrm{Si} / \mathrm{Al}$ ratio value. However, the yield of ethylene decreased monotonically with the Si/Al ratio. HZSM-5(25) zeolite gave the highest yield of ethylene (47\%).

Fig. 5(b) shows the ethanol dehydration to ethylene over Fe-ZSM-5 $(X)$ as a function of the $X\left(\mathrm{Si} / \mathrm{Al}\right.$ ratio) value at $230{ }^{\circ} \mathrm{C}$. The results showed that both the conversion of ethanol and yield of ethylene decreased uniformly with increasing $\mathrm{Si} / \mathrm{Al}$ ratio. As a result, the highest yield of ethylene (84\%) was obtained at the $\mathrm{Si} / \mathrm{Al}$ ratio of 25 .

Fig. 5(c) shows the effect of reaction temperature on the dehydration of ethanol to ethylene over Fe-ZSM-5(25). When the reaction temperature increased, the conversion of ethanol increased from $53.3 \%$ (at $200{ }^{\circ} \mathrm{C}$ ) to above $99.8 \%$ (above 260
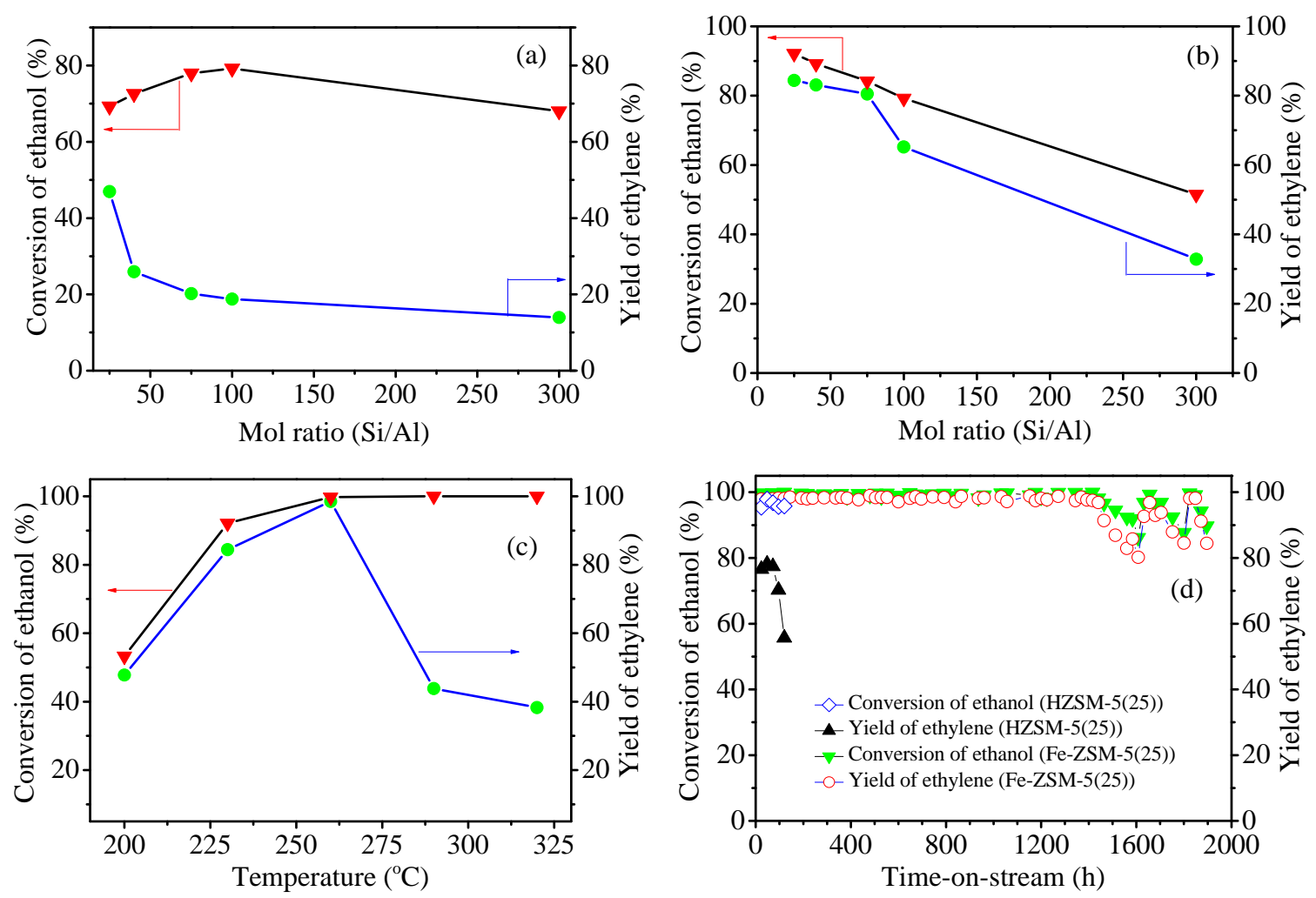

Fig. 5. Effect of $\mathrm{Si} / \mathrm{Al}$ ratio on the dehydration of ethanol to ethylene over (a) HZSM-5 $(X)$ and (b) Fe-ZSM-5 $(X)$ at reaction temperature $=230{ }^{\circ} \mathrm{C}$ and LHSV $=0.81 \mathrm{~h}^{-1}$; (c) Effect of reaction temperature on the dehydration of ethanol to ethylene over Fe-ZSM-5(25) at LHSV $=0.81 \mathrm{~h}^{-1}$; (d) Conversion of ethanol and yield of ethylene as a function of time-on-stream over HZSM-5(25) and Fe-ZSM-5(25) at reaction temperature $=260{ }^{\circ} \mathrm{C}$ and LHSV $=0.81$ $\mathrm{h}^{-1}$. 
${ }^{\circ} \mathrm{C}$ ), indicating that this reaction is accelerated by increasing the reaction temperature. However, the yield of ethylene increased first from $47.8 \%$ (at $200{ }^{\circ} \mathrm{C}$ ) to $98.5 \%$ (at $260{ }^{\circ} \mathrm{C}$ ) and then it decreased with further increase in reaction temperature. The highest ethylene yield (98.5\%) was obtained at the reaction temperature of $260^{\circ} \mathrm{C}$.

Fig. 5(d) shows the effect of time-on-stream on ethanol dehydration to ethylene over HZSM-5(25) and Fe-ZSM-5(25). At $260{ }^{\circ} \mathrm{C}$ reaction temperature and $0.81 \mathrm{~h}^{-1}$ of LHSV, $>70 \%$ of ethylene yield at $>95 \%$ ethanol conversion was obtained over HZSM-5(25), which was maintained for about 70 h. Comparatively, at the same reaction conditions, the better catalytic performance ( $>97 \%$ ethylene yield at $>98 \%$ ethanol conversion) was obtained over Fe-ZSM-5(25). The high catalytic activity was maintained for as long as $1440 \mathrm{~h}$. The outstanding stability of Fe-ZSM-5(25) indicated a very promising potential for further development.

Table 2 shows the detailed results of the conversion of ethanol over the various catalysts. According to previous work $[6,9,39,40]$, the catalytic activity for ethanol dehydration is correlated with the acid centers of the catalysts [6]. As is known, the surface acidity of a zeolite is associated with the $\mathrm{Si} / \mathrm{Al}$ ratio of zeolite. HZSM-5(25) provided a larger acid concentration than HZSM-5(300) due to the lower Si/Al ratio [41]. One can see that HZSM-5(25) (Entry 1) exhibited a similar conversion of ethanol to HZSM-5(300) (Entry 2). However, the former catalyst produced large numbers of $\mathrm{C}^{3+}$ hydrocarbons, while the latter one only gave ethylene $\left(\mathrm{C}_{2} \mathrm{H}_{4}\right)$ and diethyl ether $\left(\left(\mathrm{C}_{2} \mathrm{H}_{5}\right)_{2} \mathrm{O}\right)$. Takahara et al. [39] studied the dehydration of ethanol over various solid acid catalysts and suggested that diethyl ether is the reaction intermediate for the formation of ethylene. This was supported by Domen et al. [10] using FT-IR. Inaba et al. [21,30] and Calsavara et al. [31] studied the conversion of ethanol to hydrocarbons $[21,30,31]$ and proposed that ethanol first dehydrates to generate ethylene, which was further transformed to higher hydrocarbons and aromatics. Therefore, for HZSM-5(300), the low surface acidity led to the formation of diethyl ether as a reaction intermediate. However, for HZSM-5(25), the high surface acidity resulted in the further transformation of ethylene to $\mathrm{C}^{3+}$ hydrocarbons as byproducts.

One can see in Table 2 that after ion exchange, Fe-HZSM-5(25) (Entry 3) exhibited a higher yield of ethylene (98.52\%) than HZSM-5(25) (73.30\%). This would be due to the modification of the acidity of HZSM-5. According to Aguayo et al. [40], for the conversion of ethanol to hydrocarbons, the de- hydration of ethanol to ethylene occurs over weak acid sites, whereas the subsequent reaction steps which generate the higher hydrocarbons and aromatics require sites of a higher acid strength. The $\mathrm{NH}_{3}$-TPD results (Fig. 3 and Table 1) displayed that the ion exchange of iron decreased the total acidity of ZSM- 5 zeolite, especially the HT acid sites. As a result, the $C_{\mathrm{H}} / C_{\mathrm{L}}$ value of Fe-ZSM-5(25) (0.29) was lower than that of HZSM-5(25) (0.7). Therefore, it is reasonable that the significant reduction of the HT acid sites of HZSM- 5 by the ion exchange of iron benefited ethanol dehydration to ethylene.

One can also see in Table 2 that a relatively low reaction temperature $\left(230^{\circ} \mathrm{C}\right.$, Entry 4$)$ is propitious for the formation of the reaction intermediate diethyl ether through inter-molecular dehydration [12]. However, a relatively high reaction temperature $\left(290^{\circ} \mathrm{C}\right.$, Entry 5$)$ led to the further transformation of ethylene to $\mathrm{C}^{3+}$ hydrocarbons. Besides, the influence of LHSV on the catalytic performance was also studied. At $230{ }^{\circ} \mathrm{C}, 64.70 \%$ ethylene selectivity and $33.37 \%$ diethyl ether selectivity at 98.99\% ethanol conversion was obtained at LHSV $=0.47 \mathrm{~h}^{-1}$ (Entry 4). However, with the increase of the LHSV (Entries 6-8), the conversion of ethanol and selectivity to ethylene decreased while the selectivity to diethyl ether increased. This can be explicated by the fact that the contact time of ethanol molecules with the zeolite catalyst was shortened with the increase of LHSV, which resulted in the incomplete reaction of ethanol and led to the formation of the reaction intermediate diethyl ether [18].

Phillipes et al. [6] studied ethanol dehydration to ethylene on HZSM-5 zeolite. They found that although the Brönsted acid sites on HZSM-5 have high activity for ethanol conversion, these sites also can oligomerize ethylene to produce carbonaceous species, which rapidly cover the active sites and led to a dramatic reduction of HZSM-5 activity. Therefore, when used for ethanol dehydration to ethylene, the catalyst lifetime of a pristine HZSM-5 zeolite is usually short (below $60 \mathrm{~h}$ ) [6]. In the present work, from the FT-IR of pyridine adsorption (Fig. 2), we can see that the B/L value of Fe-ZSM-5(25) was obvious lower than that of HZSM-5(25) (the former was 0.25, and the latter was 1.42). We also can see that in Fig. 5(d), Fe-ZSM-5(25) exhibited a lifetime as long as $1440 \mathrm{~h}$ time-on-steam, which was obvious longer than the pristine HZSM-5(25) zeolite $[4,6,39]$. It was reasoned that the decrease of the amount of Brönsted acid sites on HZSM-5 by the ion exchange of iron helped increase the catalyst lifetime due to the decrease of the generation of carbonaceous species catalyzed by the Brönsted

Table 2

Catalytic reaction of ethanol over the catalysts.

\begin{tabular}{|c|c|c|c|c|c|c|c|c|c|c|c|}
\hline \multirow{2}{*}{ Entry } & \multirow{2}{*}{ Sample } & \multirow{2}{*}{$t /{ }^{\circ} \mathrm{C}$} & \multirow{2}{*}{$\operatorname{LHSV}\left(\mathrm{h}^{-1}\right)$} & \multirow{2}{*}{$\begin{array}{l}\text { Conversion of } \\
\text { ethanol (\%) }\end{array}$} & \multicolumn{6}{|c|}{ Selectivtity (\%) } & \multirow{2}{*}{$\begin{array}{c}\text { Yield of } \\
\text { ethylene }(\%)\end{array}$} \\
\hline & & & & & $\mathrm{C}_{2} \mathrm{H}_{4}$ & $\left(\mathrm{C}_{2} \mathrm{H}_{5}\right)_{2} \mathrm{O}$ & $\mathrm{C}_{2} \mathrm{H}_{6}$ and $\mathrm{C}_{3}$ & $\mathrm{C}_{4}$ & $\mathrm{C}_{5}$ & $\mathrm{C}_{6+}$ & \\
\hline 1 & HZSM-5(25) & 260 & 0.47 & 96.80 & 75.71 & 0 & 10.27 & 8.87 & 4.73 & 0.41 & 73.30 \\
\hline 2 & HZSM-5(300) & 260 & 0.47 & 96.76 & 41.41 & 58.59 & 0 & 0 & 0 & 0 & 40.07 \\
\hline 3 & Fe-ZSM-5(25) & 260 & 0.47 & 99.74 & 98.78 & 0 & 0.99 & 0.07 & 0.16 & 0 & 98.52 \\
\hline 4 & Fe-ZSM-5(25) & 230 & 0.47 & 98.99 & 64.70 & 33.37 & 0.88 & 1.03 & 0 & 0 & 64.04 \\
\hline 5 & Fe-ZSM-5(25) & 290 & 0.47 & 99.99 & 43.82 & 0 & 11.65 & 7.57 & 11.37 & 25.6 & 43.82 \\
\hline 6 & Fe-ZSM-5(25) & 230 & 0.94 & 71.57 & 58.33 & 41.47 & 0 & 0 & 0 & 0 & 41.75 \\
\hline 7 & Fe-ZSM-5(25) & 230 & 1.88 & 64.93 & 42.53 & 57.45 & 0 & 0 & 0 & 0 & 27.61 \\
\hline 8 & Fe-ZSM-5(25) & 230 & 3.79 & 55.97 & 38.19 & 71.77 & 0 & 0 & 0 & 0 & 21.37 \\
\hline
\end{tabular}


acid sites of the zeolite.

In this work, we prepared the Fe-ZSM- 5 catalyst by a method of three consecutive ion exchanges. As is known, the ion exchange method is usually employed to prepare a catalyst with a high dispersion of the metal component [42]. In Fig. 4, it was found that the Fe species was distributed over the Fe-ZSM-5 as predominantly isolated framework and extraframework $\mathrm{Fe}^{3+}$, and a small amount of oligomeric $\mathrm{Fe}_{\mathrm{x}} \mathrm{O}_{\mathrm{y}}$ clusters. However, hardly any large $\mathrm{Fe}_{2} \mathrm{O}_{3}$ particles were detected. Guan et al. [37] studied the dehydration of ethanol to ethylene over FeSBA-15 synthesized by a direct synthesis method, and showed results that suggested that isolated $\mathrm{Fe}^{3+}$ species serve as the active sites for the formation of ethylene, whereas $\mathrm{FeO}_{\mathrm{x}}$ clusters catalyzed the formation of ethylene and especially aldehyde. Therefore, in this work, the good catalytic performance of Fe-ZSM-5(25) was attributable to the large amounts of isolated framework and extraframework $\mathrm{Fe}^{3+}$ species and the low concentration of $\mathrm{FeO}_{x}$ clusters and $\mathrm{Fe}_{2} \mathrm{O}_{3}$ particles on the catalyst.

\section{Conclusions}

Iron exchanged ZSM- 5 zeolite catalysts with $\mathrm{Si} / \mathrm{Al}$ molar ratio ranging from 25 to 300 were used for ethanol dehydration to ethylene. Fe-ZSM- 5 with a $\mathrm{Si} / \mathrm{Al}$ ratio equal to 25 showed the best catalytic performance. At $260{ }^{\circ} \mathrm{C}$ and $0.81 \mathrm{~h}^{-1}$ of LHSV, $97 \%-99 \%$ yield of ethylene at $98 \%-99 \%$ conversion of ethanol was obtained, which was maintained for $1440 \mathrm{~h}$ of time-onsteam. These catalysts were characterized by XRD, $\mathrm{NH}_{3}-\mathrm{TPD}$, FT-IR of pyridine adsorption and DRS UV-VIS. The results suggested that (1) ion exchange neither deteriorated the crystal structure of HZSM-5 zeolite nor generated a new phase detectable by XRD, (2) the ion exchange of iron significantly decreased the strong acid sites of the zeolite, which benefited ethanol dehydration to ethylene, (3) the ion exchange of iron decreased the Brönsted acid sites of the zeolite, which helped extend the catalyst lifetime due to the decrease of the generation of carbonaceous species catalyzed by the Brönsted acid sites of the zeolite, and (4) the doped Fe species on the
Fe-ZSM-5 was in the form of predominantly framework and extraframework $\mathrm{Fe}^{3+}$, which increased the catalytic activity of the catalyst for ethanol dehydration to ethylene.

\section{References}

[1] M. H. Zhang, Y. Z. Yu, Ind. Eng. Chem. Res., 2013, 52, 9505-9514.

[2] Q. T. Sheng, K. C. Ling, Z. R. Li, L. F. Zhao, Fuel Process. Technol., 2013, 110, 73-78.

[3] F. Wang, M. Luo, W. D. Xiao, X. W. Cheng, Y. C. Long, Appl. Catal. A, 2011, 393, 161-170.

[4] J. D. Bi, X. W. Guo, M. Liu, X. S. Wang, Catal. Today, 2010, 149, 143-147.

[5] T. M. Nguyen, R. Le Van Mao, Appl. Catal., 1990, 58, 119-129.

[6] C. B. Phillips, R. Datta, Ind. Eng. Chem. Res., 1997, 36, 4466-4475.

[7] S. Golay, R. Doepper, A. Renken, Appl. Catal. A, 1998, 172, 97-106.

[8] J. Haber, K. Pamin, L. Matachowski, B. Napruszewska, J. Połtowicz, J. Catal., 2002, 207, 296-306.

[9] M. M. Mohamed, J. Mol. Catal. A, 2003, 200, 301-313.

[10] J. N. Kondo, K. Ito, E. Yoda, F. Wakabayashi, K. Domen, J. Phys. Chem. B, 2005, 109, 10969-10972.

[11] T. Zaki, J. Colloid Interf. Sci., 2005, 284, 606-613

[12] G. W. Chen, S. L. Li, F. J. Jiao, Q. Yuan, Catal. Today, 2007, 125, 111-119.

[13] F. Hayashi, M. Iwamoto, ACS Catal., 2013, 3, 14-17.

[14] T. Maihom, P. Khongpracha, J. Sirijaraensre, J. Limtrakul, ChemPhysChem, 2013, 14, 101-107.

[15] H. Knözinger, Angew. Chem. Int. Ed., 1968, 7, 791-805.

[16] D. Varisli, T. Dogu, G. Dogu, Chem. Eng. Sci., 2007, 62, 5349-5352.

[17] W. R. Moser, R. W. Thompson, C. C. Chiang, H. Tong, J. Catal., 1989, $117,19-32$.

[18] J. Ouyang, F. X. Kong, G. D. Su, Y. C. Hu, Q. L. Song, Catal. Lett., 2009, 132, 64-74.

[19] Y. Chen, Y. L. Wu, L. Tao, B. Dai, M. D. Yang, Z. Chen, X. Y. Zhu, J. Ind. Eng. Chem., 2010, 16, 717-722.

[20] D. S. Zhang, R. J. Wang, X. Y. Yang, Catal. Lett., 2008, 124, 384-391.

[21] M. Inaba, K. Murata, I. Takahara, React. Kinet. Catal. Lett., 2009, 97, 19-26.

[22] N. N. Zhan, Y. Hu, H. Li, D. H. Yu, Y. W. Han, H. Huang, Catal. Commun., 2010, 11, 633-637.

[23] Y. C. Hu, N. N. Zhan, C. Dou, H. Huang, Y. W. Han, D. H. Yu, Y. Hu, Biotechnol. J., 2010, 5, 1186-1191.

\section{Graphical Abstract}

Chin. J. Catal., 2016, 37: 1941-1948 doi: 10.1016/S1872-2067(16)62524-X

\section{Dehydration of bio-ethanol to ethylene over iron exchanged HZSM-5}

Baohui Chen*, Jiazheng Lu, Lianping Wu, Zisheng Chao Hunan Electric Power Corporation Disaster Prevention and Reduction Center; Hunan University

A Fe-ZSM-5(25) zeolite catalyst showed excellent activity for ethanol dehydration to ethylene. A $97 \%-99 \%$ yield of ethylene at $98 \%-99 \%$ conversion of ethanol was achieved.
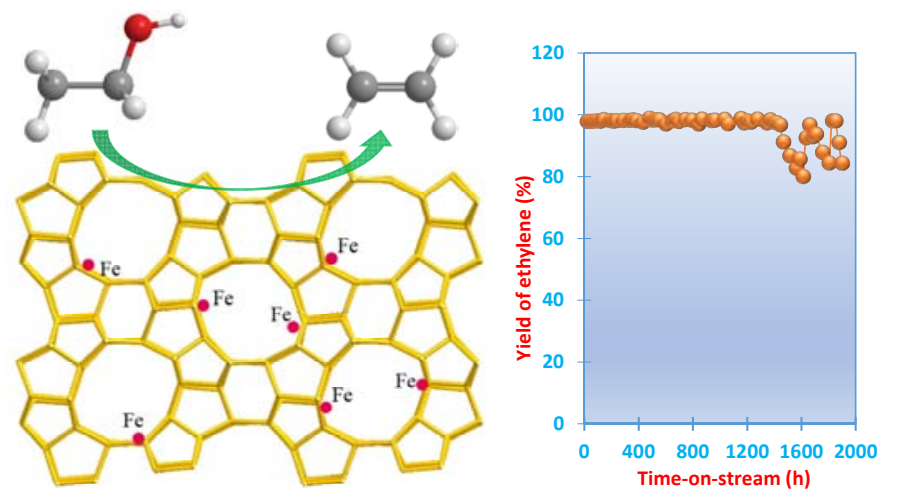
[24] R. Le Van Mao, L. H. Dao, US Patent, 4698 452, 1987.

[25] B. H. Chen, C. Huang, D. G. Huang, C. W. Luo, H. T. Li, Z. S. Chao, Appl. Catal. A, 2014, 470, 239-249.

[26] N. R. C. F. Machado, V. Calsavara, N. G. C. Astrath, C. K. Matsuda, A. P. Junior, M. L. Baesso, Fuel, 2005, 84, 2064-2070.

[27] N. R. C. F. Machado, V. Calsavara, N. G. C. Astrath, A. M. Neto, M. L. Baesso, Appl. Catal. A, 2006, 311, 193-198.

[28] S. Bun, S. Nishiyama, S. Tsuruya, M. Masai, Appl. Catal., 1990, 59, 13-29.

[29] M. Inaba, K. Murata, I. Takahara, K. I. Inoue, J. Chem. Technol. Biotechnol., 2011, 86, 95-104.

[30] M. Inaba, K. Murata, M. Saito, I. Takahara, Green Chem., 2007, 9, 638-646.

[31] V. Calsavara, M. L. Baesso, N. R. C. F. Machado, Fuel, 2008, 87, 1628-1636.

[32] E. P. Parry, J. Catal., 1963, 2, 371-379.

[33] M. Lenarda, M. Da Ros, M. Casagrande, L. Storaro, R. Ganzerla, Inorg. Chim. Acta, 2003, 349, 195-202.
[34] M. S. Kumar, M. Schwidder, W. Grünert, A. Brückner, J. Catal., 2004, 227, 384-397.

[35] J. Perez-Ramirez, M. S. Kumar, A. Brückner, J. Catal., 2004, 223, 13-27.

[36] I. O. Ali, A. M. Ali, S. M. Shabaan, K. S. El-Nasser, J. Photochem. Photobiol. A, 2009, 204, 25-31.

[37] Y. J. Guan, Y. Li, R. A. van Santen, E. J. M. Hensen, C. Li, Catal. Lett., 2007, 117, 18-24.

[38] M. S. Kumar, K. Klementiev, M. M. Pohl, A. Brückner, W. Grünert, J. Catal., 2005, 231, 314-330.

[39] I. Takahara, M. Saito, M. Inaba, K. Murata, Catal. Lett., 2005, 105, 249-252.

[40] A. T. Aguayo, A. G. Gayubo, A. M. Tarrío, A. Atutxa, J. Bilbao, J. Chem. Technol. Biotechnol., 2002, 77, 211-216.

[41] R. Borade, A. Sayari, A. Adnot, S. Kaliaguine, J. Phys. Chem., 1990, 94, 5989-5994.

[42] B. H. Chen, Z. S. Chao, H. He, C. Huang, Y. J. Liu, W. J. Yi, X. L. Wei, J. F. An, Dalton Trans., 2016, 45, 2720-2039.

\title{
生物质乙醇在 Fe-HZSM-5 分子篮催化剂上脱水制乙烯
}

\author{
陈宝辉 ${ }^{a, b}$, $^{*}$ 陆佳政 ${ }^{\mathrm{a}}$, 吴莲萍 ${ }^{\mathrm{b}}$, 泉自胜 ${ }^{\mathrm{b}}$ \\ a电网输变电设备防灾减灾国家重点实验室, 国网湖南省电力公司防灾减灾中心, \\ 国家电网公司输变电设备防冰减灾技术重点实验室, 湖南长沙 410007

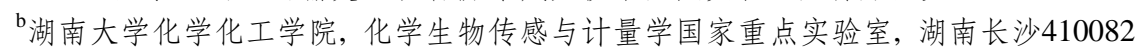

摘要: 乙烯是一种重要的大宗化工原料. 目前国内外乙烯的生产方法主要是石脑油裂解法. 但是, 随着全球性石油资源供 求关系日趋紧张, 以及该生产过程存在较大环境污染, 该工艺面临严峻挑战. 生物乙醇是一种可以通过生物质发酵获得的 可再生资源. 因此, 生物质乙醇催化脱水制乙烯工艺受到越来越多研究者关注. 该技术的关键在于高性能乙醇脱水制乙烯 催化剂的开发. 研究发现, Si/Al 比大于 40 的 Fe 改性 ZSM-5 分子篮在乙醇转换制碳氢化合物的催化反应中具有较高活 性, 当反应温度大于 $400{ }^{\circ} \mathrm{C}$ 时, 可生成 $\mathrm{C}_{1}-\mathrm{C}_{9}$ 的烷烃、烯烃和芳香烃, 其中以 $\mathrm{C}_{3}$ 产物和芳香烃产物为主. 本文研究了 $\mathrm{Si} / \mathrm{Al}$ 比为 25-300 的 Fe 离子交换 ZSM-5 分子笁在乙醇脱水制乙烯反应中的催化活性, 并利用 XRD, NH 3 -TPD, 吡啶吸附 FT-IR 和DRS UV-VIS 等表征手段, 研究了催化剂的晶相结构、表面组成及酸性位点等, 进而探究了该催化反应的反应机理.

我们首先考察了 Si/Al 比为 25-300 的 HZSM-5 分子笁. 随着分子耖 Si/Al 比增大, 乙醇转化率先增加后降低, 在 Si/Al 比为 100 时获得最高值; 但是乙烯收率随着 $\mathrm{Si} / \mathrm{Al}$ 比的增加而持续下降, $\mathrm{Si} / \mathrm{Al}$ 比为 25 时有其最高值 $47 \%$. 经产物分析, HZSM-5(25) 和 HZSM-5(300) 虽具有相似的乙醇转化率, 但前者产生大量 $\mathrm{C}_{3+}$ 产物, 而后者产物只有乙烯和乙醚. 据文献报 道, 乙醚是乙醇脱水制乙烯的中间产物, 它的进一步脱水产生乙烯, 而乙烯可进一步转化生成 $\mathrm{C}_{3+}$ 产物. 因此, 由于 HZSM-5(300) 表面酸性较弱, 主要生成反应中间体, 而 HZSM-5(25) 较强的表面酸性又导致乙烯进一步转化, 生成 $\mathrm{C}_{3+}$ 产物. 然后我们考察了经过 3 次离子交换处理的 Fe-ZSM-5 催化剂. 随着 Si/Al 比上升 (25-300), 乙醇转化率和乙烯收率下降, $\mathrm{Si} / \mathrm{Al}$ 比为 25 时为其最高值; 随着反应温度上升, 乙醇转化率在 $260{ }^{\circ} \mathrm{C}$ 时达到近 $100 \%$, 之后维持不变, 乙烯收率也在 260 ${ }^{\circ} \mathrm{C}$ 时为其峰值, 温度继续上升造成乙烯收率再次下降; 催化剂空速增大降低乙醇转化率和乙烯收率. 经产物分析, 温度较 低和空速较大时产生大量的反应中间体乙醚, 而温度较高时导致乙烯进一步转化生成 $\mathrm{C}_{3+}+\frac{\bar{y}}{}$ 物. 在反应温度为 $260{ }^{\circ} \mathrm{C} 、$ 空 速为 $0.81 \mathrm{~h}^{-1}$ 时, Fe-HZSM-5(25) 催化剂上乙醇转化率为 98\%-99\%、乙烯收率为 97\%-99\%, 并可实现长达 $1440 \mathrm{~h}$ 的单程使 用寿命, 该值是 HZSM-5(25) 催化剂的 20 余倍, 具有很好的工业应用前景.

为探究 Fe-ZSM-5(25) 催化剂高催化活性和长催化寿命的原因, 我们表征了催化剂. 从 XRD 结果可以看出, 离子交换 没有损坏 HZSM-5 的晶体结构, 也没有新的可检测到的物相产生. 从 $\mathrm{NH}_{3}$-TPD 结果看, HZSM-5(25) 的 $C_{\mathrm{H}} / C_{\mathrm{L}}$ (强酸/弱酸) 比为 $0.7, \mathrm{Fe}-\mathrm{ZSM}-5(25)$ 的 $C_{\mathrm{H}} / C_{\mathrm{L}}$ 比为 0.29 , 可知 $\mathrm{Fe}$ 离子交换降低了分子笁的表面酸性, 特别是强酸性位. 从吡啶吸附 FT-IR 结果看, HZSM-5(25) 的 B/L (Brönsted 酸性位/Lewis 酸性位) 比为 1.42, Fe-ZSM-5(25) 的 B/L 比为 0.25 , 可知 Fe 离 子交换主要减少的是分子笁表面的 Brönsted 酸性位. 文献报道, 乙醇脱水制乙烯主要发生在弱酸性位上, 而乙烯进一步转 化为 $\mathrm{C}_{3+}$ 产物发生在强酸性位上. 所以, 催化剂上强酸性位的减少有利于乙烯的生成反应. 另据文献报道, Brönsted 酸性位 是乙烯聚合、迅速覆盖催化活性位点产生积炭的催化活性中心. 因此, Brönsted 酸性的降低可认为是 Fe-HZSM-5(25) 催化 剂单程使用寿命长较 HZSM-5(25) 分子篮显著延长的原因. 从 UV-VIS 结果得知, Fe-ZSM-5 上的 Fe 物种主要以骨架内和 骨架外 $\mathrm{Fe}^{3+}$ 为主, 此外含有少量低聚合的 $\mathrm{Fe}_{x} \mathrm{O}_{y}$, 但几乎没有 $\mathrm{Fe}_{2} \mathrm{O}_{3}$ 颗粒存在. 文献记载, $\mathrm{Fe}^{3+}$ 物种是乙烯形成的活性物种, 
而 $\mathrm{FeO}_{x}$ 催化产生乙烯和乙醛. 因此, 催化剂中大量骨架内和骨架外 $\mathrm{Fe}^{3+}$ 物种的存在也可认为是该催化剂具有较强乙醇脱 水制乙烯催化活性的原因之一.

关键词: 铁; ZSM-5; 脱水; 乙醇; 乙烯

收稿日期: 2016-05-27. 接受日期: 2016-08-03. 出版日期: 2016-11-05.

*通讯联系人. 电话/传真: (0731)86332074; 电子信箱: bymountains@gmail.com

基金来源：国家自然科学基金 (21376068); 中国博士后科学基金 (2016M592424).

本文的英文电子版由Elsevier出版社在ScienceDirect上出版(http://www.sciencedirect.com/science/journal/18722067). 